\title{
USE OF SCIENTIFIC ERGONOMIC PROGRAMMES TO IMPROVE ORGANISATIONAL PERFORMANCE
}

\author{
R. Roopnarain ${ }^{1}$, M. Dewa ${ }^{1}$ \& K.R. Ramdass ${ }^{2}$
}

\section{ARTICLE INFO}

Article details

Presented at the $30^{\text {th }}$ annual conference of the Southern African Institute for Industrial Engineering (SAIIE), held from 30 September - 2 October 2019 in Port Elizabeth, South Africa

Available online

15 Nov 2019

\section{Contact details \\ * Corresponding author riashna.r@gmail.com}

\section{Author affiliations}

1 Department of Industrial Engineering, Durban University of Technology, South Africa

2 Department of Industrial Engineering, University of South Africa, South Africa

DOI

http://dx.doi.org/10.7166/30-3-2229
The packaging industry is characterised by ineffective ergonomic programmes that are inadequately implemented, thus failing to yield benefits in an organisation's overall performance. The aim of the study is to determine an effective scientific ergonomic programme to improve an organisation's overall performance by aligning these programmes with its business strategy. A quantitative analysis was conducted at two sites of a liquid packaging company in South Africa using a sample of 70 participants from the production and engineering departments. It was found that several factors hindered the effective implementation of ergonomics in the packaging industry. These factors include awareness, human computer interaction, job task design, poor implementation of anthropometric and physiological factors, poor communication, and a disconnection between employees and organisational strategies. It was recommended that the organisation orientate and train employees on ergonomic best practices to create an effective programme to address the operational gaps and enhance the organisation's overall performance.

\section{OPSOMMING}

Die verpakkingsindustrie word gekenmerk deur oneffektiewe ergonomie programme wat swak implementeer word. Dit bied dus nie tasbare voordele in ' $\mathrm{n}$ organisasie se algehele vertoning nie. Die doel van hierdie studie is om 'n wetenskaplik gefundeerde ergonomie program te formuleer wat belyn is met die maatskappy se besigheid-strategie om sodoende ' $n$ verbetering in die maatskappy se algehele doeltreffendheid te behaal. 'n Kwantitatiewe analise is by twee vloeistofverpakkingsaanlegte in Suid-Afrika van stapel gestuur met 'n proefsteek van 70 deelnemers van die produksie en ingenieurswese afdelings. Daar is gevind dat verskeie faktore die doeltreffende implementering van ergonomie verhinder. Hierdie faktore sluit in bewustheid, mens-rekenaar interaksie, werksopdrag ontwerp, swak implementering van antropometriese en fisiologiese faktore, swak kommunikasie en swak belyning tussen werknemers en organisatoriese strategieë. Die aanbeveling is dat die organisasie sy werknemers beter inlig en oplei aan die hand van beste praktyke met betrekking tot ergonomie om 'n doeltreffende program wat hierdie tekortkominge aanspreek te skep.

Ergonomics is defined as the scientific discipline that is concerned with how humans interact with the tools and equipment they use while performing tasks and other activities [1]. It uses the knowledge of human abilities and limitations when designing systems, organisations, jobs, machinery, and products [2]. The main objective of ergonomics is to improve performance, health, and safety. Important aspects, such as work schedule, job design, interpersonal aspects, career 
concerns, and organisational characteristics, all have a direct impact on attaining these objectives [3].

It has been found that ergonomics in industrially developed countries is not well understood in practice, and is thus not accepted as an integral part of organisational success or worker well-being [4]. This study will focus on determining an effective scientific ergonomic programme that can be implemented in the packaging industry to assist in improving the overall performance of employees, and create a productive and efficient working environment that will deliver organisational effectiveness. The objective of this paper is to assess employees' perceptions of the current ergonomics scenario in the packaging industry, to determine the current ergonomics gaps and the condition of the packaging industry, and to develop and integrate an effective ergonomic programme with the current working processes that will contribute to organisational improvement.

\section{LITERATURE REVIEW}

According to the scientific literature, creating a healthy work place is important [5]. In the manufacturing industry, workers are often placed in high-risk working environments where they are more susceptible to injuries.

The goal of implementing ergonomic interventions and the use of ergonomic science is to achieve a suitable relationship between staff and work, where staff can achieve maximum productivity and production. Ergonomics has been recognised as a scientific discipline that explores the capabilities and limitations, and uses this knowledge to improve the design of things that people use and the ways in which they work. Ergonomics is considered an important element in how a company realises its strategic goals. In order for a company to realise the full benefits of ergonomics, it will deliberately have to integrate ergonomics into all its strategic goals and at all levels of the organisation [6].

Advanced technologies with which humans interact today are complex systems that require a high level of integration from both design and management perspectives [7]. With the introduction of the Fourth Industrial Revolution, systems become more complex in the interaction between hardware, and information systems, and people become an integral part of systems and processes being effective. Human system integration is seen as an element of systems engineering that is concerned with understanding, designing, and supporting human roles and performance in complex systems [8]. Being proactive about ergonomic work means foreseeing ergonomics problems and quality risks, based on both scientific research and practical experience [9].

While research on ergonomic programmes implemented in the packaging industry is limited, ergonomics applied in the manufacturing sector as a whole have proven to be well received $A$ key objective of this paper was to determine the relationship between these influences on an individual and their work performance. The main question under investigation is the impact that ergonomic programmes have on the overall organisational performance.

\section{RESEARCH METHODOLOGY}

A questionnaire was developed to identify the causes to which employees attribute poor performance in the packaging industry. All ethical precautions were taken and abided by, according to the National Institute of Health Office of Extramural Research. The survey consisted of 37 questions relating to the different factors in ergonomics, and were adapted from the handbook Human factors and ergonomics by Karwowski (2012).

The research conducted for this current study was quantitative. The reason for utilising this methodology is that it allows the current gaps in and concerns about ergonomic programmes on site to be identified, through analysing the data.

The target population for this research was focused on the engineering team and the machine operators the machine operators, maintenance supervisors, artisans and operators in the production teams from the company's two sites, in Cape Town and Durban.

Table 1 presents a record of the engineering and production teams from the different sites that participated in the survey. 
Table 1: Sample size at the Cape Town and Durban sites

\begin{tabular}{|l|c|c|}
\hline \multirow{2}{*}{ Trade } & Cape Town site: Epping & Durban: Pinetown site \\
\cline { 2 - 3 } & 28 & 4 \\
\hline Bagger operator & 8 & 10 \\
\hline Machine operator & 1 & 0 \\
\hline Gate keeper & 1 & 4 \\
\hline Setter & 2 & 1 \\
\hline Quality control inspector & 1 & 4 \\
\hline Technician & 1 & 0 \\
\hline Demand planner & 1 & 1 \\
\hline Operator (Polyethylene terephthalate) & 0 & 3 \\
\hline Material controller & 43 & 27 \\
\hline Grand Total & & \multicolumn{2}{|c|}{} \\
\hline
\end{tabular}

A pilot study was conducted by sending the questionnaires to management, who reviewed the content and context of the questions to verify whether their employees would be able to understand and complete the questionnaires. The questionnaires were then administered face-to-face on both sites. This method also ensured that the responses were accurate and reliable. To simplify the data analysis process, the data was arranged in various categories relating to ergonomic programmes: anthropometry, physiological, work posture, task design, information tasks, human computer interaction, illumination, and noise and vibration.

Internal validity is vital in determining whether the conclusions that are reached in research accurately reflect what was being studied [10]. The ten threats applied in this study to conduct internal validation were history, maturation, regression, selection, mortality, diffusion of treatment, compensatory or resentful demoralisation, compensatory rivalry, testing, and instrumentation.

In this study, all forms of bias were avoided, as the sample size did not discriminate on the basis of gender, age, or race. All employees who fell within the research pool had an equal opportunity to complete the questionnaire. All ethical considerations were also taken into account and abided by, according to the National Institute of Health Office of Extramural Research.

\section{$4 \quad$ RESULTS AND FINDINGS}

The results from each question were tabulated for analysis. The data from both sites were also combined to simplify the interpretation of the statistics.

Below are the findings from the packaging companies based in Cape Town (Epping) and Durban (Pinetown):

\subsection{Demographics findings}

Table 2: Occupations of research participants

\begin{tabular}{||l|c|c|c|}
\hline & Frequency & Percentage & Cumulative percentage \\
\hline Bagger operator & 32 & 45.7 & 45.7 \\
\hline Machine operator & 18 & 25.7 & 71.4 \\
\hline Gate keeper & 1 & 1.4 & 72.9 \\
\hline Setter & 5 & 7.1 & 80.0 \\
\hline Quality control inspector & 3 & 4.3 & 84.3 \\
\hline Technician & 5 & 7.1 & 91.4 \\
\hline Demand planner & 1 & 1.4 & 92.9 \\
\hline Operator (Polyethylene terephthalate) & 2 & 2.9 & 95.7 \\
\hline Material Controller & 3 & 4.3 & 100.0 \\
\hline Total & 70 & 100.0 & \\
\hline
\end{tabular}

Table 2 shows the occupation count of the participants who completed the survey. At both sites, the greatest number of the participants were bagger operators. Their job responsibilities consist of frequent manual tasks that often lead to exhaustion. 


\subsection{Results relating to ergonomic factors}

Table 3: Mean values for anthropometric and physiological factors

\begin{tabular}{|l|c|c|}
\hline \multicolumn{3}{|c|}{ Anthropometric \& physiological factors } \\
\hline \multicolumn{1}{|c|}{ Options } & $\mu$ & $\mu(\%)$ \\
\hline Strongly agree & 10 & $28 \%$ \\
\hline Agree & 37 & $53 \%$ \\
\hline Neutral & 11 & $7 \%$ \\
\hline Disagree & 8 & $11 \%$ \\
\hline Strongly disagree & 2 & $3 \%$ \\
\hline
\end{tabular}

Table 3 displays the overall average results received in the anthropometric and physiological categories. From a sample size of seventy, the overall feedback is positive, as most of the participants responded with 'agree' and 'strongly agree'. However, feedback that chose the 'neutral', 'disagree', and 'strongly disagree' options, will need to be addressed in the improvement plane.

Table 4: Mean values of the survey results related to working posture

\begin{tabular}{|l|c|c|}
\hline \multicolumn{3}{|c|}{ Factors related to working posture } \\
\hline Options & $\mu$ & $\mu(\%)$ \\
\hline Strongly agree & 5 & $8 \%$ \\
\hline Agree & 25 & $36 \%$ \\
\hline Neutral & 11 & $16 \%$ \\
\hline Disagree & 24 & $34 \%$ \\
\hline Strongly disagree & 2 & $3 \%$ \\
\hline
\end{tabular}

Table 4 displays the overall mean results received in the working posture category of the survey. From a sample size of seventy, the results show that most of the feedback received chose the 'agree' and 'disagree' options. The participants that selected 'disagree' and 'strongly disagree' option will need to be addressed in the improvement plane.

Table 5: Mean values of the survey results related to task and job design

\begin{tabular}{|l|c|c|}
\hline \multicolumn{3}{|c|}{ Factors related to the design of tasks and jobs } \\
\hline Options & $\mu$ & $\mu(\%)$ \\
\hline Strongly agree & 10 & $14 \%$ \\
\hline Agree & 28 & $40 \%$ \\
\hline Neutral & 10 & $15 \%$ \\
\hline Disagree & 16 & $23 \%$ \\
\hline Strongly disagree & 4 & $6 \%$ \\
\hline
\end{tabular}

Table 5 displays the overall average results received in the task and job design category. From a sample size of seventy, the overall feedback is positive, as most of the participants responded with 'agree' and 'strongly agree'. However, feedback that chose the 'neutral', 'disagree', and 'strongly disagree' options will need to be addressed in the improvement plane.

Table 6: Mean values of the survey results relating to information tasks

\begin{tabular}{|l|r|r|}
\hline \multicolumn{3}{|c|}{ Factors related to information tasks } \\
\hline Options & $\mu$ & $\mu(\%)$ \\
\hline Strongly agree & 5 & $6 \%$ \\
\hline Agree & 40 & $60 \%$ \\
\hline Neutral & 11 & $16 \%$ \\
\hline Disagree & 10 & $14 . \%$ \\
\hline Strongly disagree & 4 & $4 \%$ \\
\hline
\end{tabular}

Table 6 displays the overall average results received in the information tasks category. From a sample size of seventy, the overall feedback is positive' as most of the participants responded with 'agree' and 'strongly agree'. However, feedback that chose the 'neutral', 'disagree', and 'strongly disagree' options will need to be addressed in the improvement plane. 
Table 7: Mean values of the survey results related to human-computer interaction

\begin{tabular}{|l|r|r|}
\hline Human-computer interaction \\
\hline Options & \multicolumn{1}{|c|}{$\boldsymbol{\mu}$} & $\boldsymbol{\mu ( \% )}$ \\
\hline Strongly agree & 2 & $3 \%$ \\
\hline Agree & 10 & $14 \%$ \\
\hline Neutral & 5 & $7 \%$ \\
\hline Disagree & 5 & $7 \%$ \\
\hline Strongly disagree & 2 & $3 \%$ \\
\hline
\end{tabular}

Table 7 displays the overall average results received in the human-computer interaction category. From a sample size of seventy, only twenty-four participants found these questions applicable, as very few employees make use of computers. From the results received from the relevant employees, it can be deduced that there is a gap between the operational activities that include the use of computers and the employees.

Table 8: Mean values of the survey results related to illumination

\begin{tabular}{|l|c|c|}
\hline \multicolumn{3}{|c|}{ Factors related to illumination } \\
\hline Options & $\mu$ & $\mu(\%)$ \\
\hline Strongly agree & 5 & $7 \%$ \\
\hline Agree & 31 & $44 \%$ \\
\hline Neutral & 12 & $17 \%$ \\
\hline Disagree & 18 & $26 \%$ \\
\hline Strongly disagree & 3 & $5 \%$ \\
\hline
\end{tabular}

Table 8 displays the overall average results received in the lighting and illumination category. The results obtained in this category indicates that most of the participants approve of the current lighting conditions at the sites. However, a high percentage disapproved of the current lighting conditions; this needs to be addressed to prevent any risk of injury or poor performance related to lighting and illumination.

Table 9: Mean values of the survey results related to noise and vibration

\begin{tabular}{|l|c|c|}
\hline Factors related to noise and vibration \\
\hline Options & $\mu$ & $\mu(\%)$ \\
\hline Strongly agree & 4 & $6 \%$ \\
\hline Agree & 27 & $39 \%$ \\
\hline Neutral & 14 & $19 \%$ \\
\hline Disagree & 18 & $26 \%$ \\
\hline Strongly disagree & 5 & $7 \%$ \\
\hline
\end{tabular}

Table 9 displays the overall average results received in the noise and vibration category. The results obtained in this category also indicate the need for an improvement plan, as a high percentage responded in the 'neutral', 'disagree', and 'strongly disagree' options.

After reviewing the results and findings in this study, it is clear that there is a huge gap in the implementation of ergonomic programmes; an intervention is thus essential. At the beginning of the research, the objective set to achieve first was to assess and understand the employees' perceptions of the current ergonomic scenario in the packaging industry, to determine the current ergonomic gaps and conditions, and thereafter to develop recommendations and improvements that would positively contribute to the organisation's overall performance.

\subsection{Current ergonomic scenario, and perceptions of the packaging industry}

Industrial ergonomics investigates the human and system relationships at an individual workplace (workstation) level or at the work system level. It embraces knowledge that is also of central interest to management [11]. Management in manufacturing industries used to associate ergonomics with the Occupational Health and Safety department, and not with engineering or overall organisational effectiveness. This impeded the success and growth opportunities that ergonomic programmes might have had. However, recent literature has shown that management in the manufacturing and packaging sector is beginning to understand and value the benefits such programmes can have for employee performance, quality, productivity, and lead time. The current literature shows that research conducted in the packaging industry relating to ergonomics is limited, while ergonomics applied in the manufacturing sector as a whole has proven to be well-received. 


\subsection{Determining the current ergonomics gaps, and the condition of the packaging industry}

Two packaging sites were studied to determine the prevalence of ergonomics in the packaging sector. The results indicated the gaps and current conditions relating to ergonomics. It was found that there is a huge gap in knowledge about the basic principles and fundamentals of ergonomics. While most workers understood their purpose and job expectation, none of them understood how factors such as safety procedures, operational performance, and employee best practices fitted into the bigger picture of the organisation.

Departments working in isolation can also be a major barrier to organisational effectiveness. Another finding was that the older members of the work force - those, older than thirty-six years, - had little knowledge of ergonomic interventions. It was also found that the use of computers was restricted to a few employees. The idea of automating processes to make job tasks much easier would not be an easy fix, as the gap between technology and business operations in industrial developing countries is still a major problem that needs to be addressed.

\section{RECOMMENDATIONS FOR DEVELOPING AN EFFECTIVE ERGONOMIC PROGRAMME}

An ergonomic intervention is defined as a well-planned, structured process for thinking and action at three levels in an organisation, - individual, group, and organisational, to instigate change, that is suitable for the work systems in question. It is important that the ergonomist receives a professional evaluation and improvement of the work system through the participation of the workers in action. The benefits of ergonomic interventions are not yet well-known to most people in industrial developing countries. The most common reason is the general lack of knowledge and awareness about ergonomics and its positive contribution to health, safety, productivity, and quality of work [12].

In this case it was vital to propose recommendations for developing an effective ergonomic programme for the current working processes that would contribute to organisational improvement. After identifying the gaps relating to the lack of knowledge and the ignorance about ergonomics programmes, it was evident that an intervention was needed. Due to time constraints, the proposed solution to monitor the overall improvement has not yet been implemented; however, the proposed intervention was deemed valuable.

Systems engineering establishes the technical framework for delivering and providing the foundation on which everything else is built, and it supports programme success. It ensures the effective development and delivery of capability through the implementation of a balanced approach aligned to cost, schedule, performance, and risk, using integrated, disciplined, and consistent activities and processes regardless of when a programme enters the acquisition life cycle [13]. Integrating methodologies and processes adopted by systems engineering with ergonomic best practices will ensure that the ergonomic intervention is sustainable and addresses the identified gaps in the business.

An important process that is involved in the technical planning process of systems engineering is the implementation of the risk assessment. Risk assessment is the determination of the measure and value of risk related to an existing situation and a known threat, which forms an essential part of known programmes [14]. The proposal of integrating risk assessment with ergonomic programmes will address the current gaps identified in the results from the questionnaires, and will help to build a sustainable programme that is aligned with the organisation's needs.

The procedure of the programme will entail a criticality analysis related to ergonomic factors, such as the example below: 


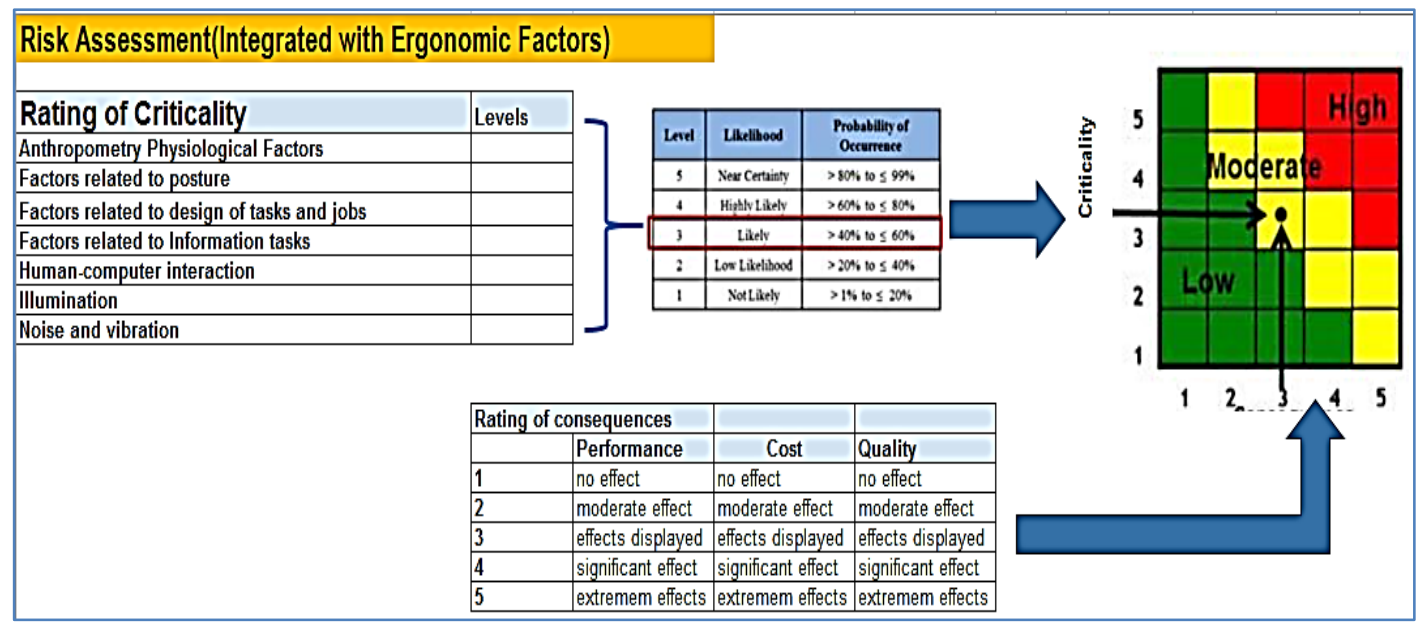

Figure 1: Ergonomic intervention integrated with risk assessment methodology

Figure 1 illustrates how both processes can be integrated as an intervention to identify current gaps that impede performance and growth opportunities. The procedure of the programme will entail a criticality analysis related to ergonomic factors, such as the example in Figure 1 . The levels of criticality will be scored by a matrix and the 'rating of consequences' table. The result of the assessment will then identify the priority of the ergonomic factors. Based on the priority scale (low, moderate, high), action plans can be developed to resolve the current pain points that impede organisational performance. The action plans can vary from the implementation of ergonomic checkpoints to failure mode analysis tools.

\section{6}

CONCLUSION

From the findings and results identified in this research, it is evident that the value of ergonomics extends beyond health and safety. Ergonomic programmes help organisations to achieve high performance through holistic measures. While research in the packaging sector is limited, the existing literature highlights the value and benefits that ergonomics interventions have in the manufacturing industry. Holistically, a lot more can be done in the field of ergonomics in the packaging sector; it is thus important that organisations foster a culture that aligns their operational processes with ergonomic best practices.

\section{REFERENCES}

[1] Groover, M.P. 2007. Work system and the methods, measurements and management of work,Upper Saddle River, NJ: Pearson Prentice Hall.

[2] Wilson, J.R. 2000. Fundamentals of ergonomics in theory and practice. Applied Ergonomics, 31(6), pp. 557-567.

[3] Temple, R. and Adams, T., 2000. Ergonomic analysis of a multi-task industrial lifting station using the NIOSH method. Journal of industrial technology, 16(2), pp.1-6

[4] Ngcamu, N.S. 2009. Awkward working postures and precision performance as an example of the relationship between ergonomics and production quality. Grahamstown: Rhodes University.

[5] Järvis, M., Virovere, A.\& Tint, P. 2016. Formal safety versus real safety: Quantitative and qualitative approaches to safety culture - evidence from Estonia. In: Proceedings of the Latvian Academy of Sciences. Section B. Natural, Exact, and Applied Sciences, pp. 269-277.

[6] Garcia-Lorenzo, A., Carlos Prado Prado, J.\& García Arca, J. 2000. Continuous improvement and employee participation in SMEs. The TQM Magazine, 12(4), pp. 290-294.

[7] Karwowski, W., 2012. The discipline of human factors and ergonomics. Handbook of human factors and ergonomics, 4, pp.3-37

[8] Salvendy, G. ed., 2012. Handbook of human factors and ergonomics. John Wiley \& Sons.

[9] Falck, A.-C. \& Rosenqvist, M. 2012. What are the obstacles and needs of proactive ergonomics measures at early product development stages? An interview study in five Swedish companies. International Journal of Industrial Ergonomics, 42(5),pp. 406-415.

[10] Calero, L.M., 2015. Are schools intervening? A longitudinal, descriptive study on RTI's effectiveness and impact on the number of students with an IEP (Doctoral dissertation, Capella University)

[11] Karwowski, W. 2005. Ergonomics and human factors: The paradigms for science, engineering, design, technology and management of human-compatible systems. Ergonomics, 48(5), pp. 436-463. 
[12] Helali, F., 2008. Developing an ergonomics intervention technique model to support the participatory ergonomics process for improving work systems in organizations in an industrially developing country and its 'Meta-Reflection' (Doctoral dissertation, Luleå tekniska universitet).

[13] Vesonder, G., Verma, D., Hutchinson, N., Luna, S., Miller, W., Tao, H.Y. and Wade, J., 2018. Mission Engineering Competencies Technical Report. Stevens Institute of Technology Hoboken United States

[14] Akinsolu, M.O., 2013, April. The Role of Risk Assessment in Engineering Practice. In 12th Research Seminar Series Workshop. 